$\begin{array}{lr} & \begin{array}{r}\text { Forum Pedagogiczne } \\ 11(2021) 1\end{array} \\ \text { EMILIA ŚMIECHǪło: 18.07.2020 } \\ \text { Warszawa, Polska } \\ \text { ORCID ID: https://orcid.org/oooo-0oo2-6522-3817 }\end{array}$

\title{
DYSKURSY NIEPEŁNOSPRAWNOŚCI W LITERATURZE DZIECIĘCEJ
}

\begin{abstract}
Streszczenie: W literaturze dziecięcej i książkach dla dzieci nieczęsto podejmowana jest tematyka niepełnosprawności, choć obrazowanie bohaterów o niepełnej sprawności jest ważne zarówno z perspektywy odbiorcy bez dysfunkcji, jak i doświadczającego utrudnień w funkcjonowaniu psychofizycznym. Tymczasem zauważa się, że wiele negatywnych stereotypów jest utrwalanych poprzez przekaz literacki. Celem artykułu jest wydobycie tekstów kultury, które podejmują temat niepełnosprawności, ale nie ograniczają się jedynie do pełnienia funkcji służebnej względem społecznych prointegracyjnych potrzeb, lecz proporcjonalnie łączą walory etyczne i estetyczne.
\end{abstract}

Słowa kluczowe: literatura dziecięca, niepełnosprawność, włączanie, niewidomy, niepełnosprawny intelektualnie, książka dla dzieci.

\section{Wprowadzenie}

Obrazowanie niepełnosprawności i bohaterów z niepełnosprawnością we współczesnych książkach dla dzieci i w literaturze dziecięcej, zwłaszcza skierowanych do odbiorców w młodszym wieku szkolnym, jest zjawiskiem ważnym z perspektywy społeczno-kulturowej. Książki stanowią lustro, w którym dzieci mogą zobaczyć postacie wyglądające tak jak one, mające podobne odczucia i doświadczenia. Książki stanowią także okno, przez które dzieci mają dostęp do świata poza ich bezpośrednim otoczeniem, poznając postacie i zdarzenia, które występują w innych wspólnotach lub innych częściach świata (Rudman, Pearce 1988; Rudman 1995). Ustalenie, czy dzieci z niepełnosprawnością - odbiorcy tekstów kultury, mogą

\footnotetext{
* Dr Emilia Śmiechowska-Petrovskij, Uniwersytet Kardynała Stefana Wyszyńskiego w Warszawie, Wydział Nauk Pedagogicznych; e-mail: e.smiechowska@uksw.edu.pl.
} 
w nich odnaleźć bohaterów i sytuacje im bliskie oraz czy dzieci pełnosprawne mogą dzięki literaturze dziecięcej i książkach dla dzieci uzyskać wgląd w świat rówieśników o utrudnionym rozwoju, zyskuje na znaczeniu wobec normalizującego i inkluzyjnego podejścia do niepełnosprawności, również w obszarze edukacyjnym. Kształcenie włączające dzieci ze specjalnymi potrzebami edukacyjnymi jest trendem w szkolnictwie światowym. W Polsce jest ok. 130 tys. uczniów z niepełnosprawnościami (ok. 3,5 proc. wszystkich uczniów), spośród których 60,9 proc. stanowią uczęszczający do szkół ogólnodostępnych na pierwszym etapie edukacji (Oświata i Wychowanie w roku szkolnym 2018/2019, dokument elektroniczny).

Sposobność do zapoznawania się z treściami odnoszącymi do problematyki niepełnosprawności w tekstach kultury dla dzieci rozszerza ich horyzont poznawczy - pomaga kształtować świadomość zróżnicowania społecznego pod względem możliwości fizycznych i intelektualnych jednostek, podobnie jak ma to miejsce w przypadku zróżnicowania kulturowego (Connor, Gabel 2010). Ponadto dzieciom w młodszym wieku szkolnym dostęp do takich treści ułatwia tworzenie reprezentacji pojęciowych niepełnosprawności i budowanie schematu relacji z osobami z niepełną sprawnością w przyszłości. Odbiorcy z niepełnosprawnościami, odnajdujący w treściach lektur postacie o zbliżonych cechach, mogą z kolei wyzyskiwać mechanizm pozytywnej identyfikacji.

Analizowanie dyskursów ${ }^{1}$ niepełnosprawności w literaturze dziecięcej i w książkach dla dzieci ulokować należy na styku socjologii komunikacji literackiej i pedagogiki specjalnej. Problemy badawcze z jednej strony dotyczyć będą ilościowego aspektu problematyki niepełnosprawności w literaturze (wydobycie pozycji wydawniczych i liczebnościowe określenie skali zjawiska), z drugiej strony jakościowych walorów jej uobecnienia: stopnia zbliżenia reprezentacji tematu do rzeczywistości empirycznej oraz funkcji społecznej tekstów literackich podejmujących zagadnienie niepełnosprawności. Perspektywa pedagogiki specjalnej będzie pogłębiać te eksploracje, $\mathrm{z}$ akcentem położonym na rzetelność przekazywanych informacji o niepełnosprawności i wzbogacanie wiedzy o realnych potrzebach i możliwościach jednostek o utrudnionym rozwoju, dając możliwość wykorzystania tekstów literackich w celu kształtowania postaw względem osób doświadczających dysfunkcji i promowania pożądanych wzorców zachowań oraz pozwalając dorosłym pośrednikom (nauczycielom, rodzicom, edukatorom) wykorzystać teksty literackie w pracy z dzieckiem.

Dzieci z niepełnosprawnościami ogólnie rzadko stają się bohaterami tekstów literackich. Ich prezentacja ma charakter dualistyczny. Z osobą z niepełnosprawnością kojarzone są takie kategorie, jak litość lub patos, a bohater z niepełnosprawnością,

1 Pojęcie dyskursu używane jest w artykule zgodnie z podejściem socjologicznym, według którego dyskurs jest praktyką wypowiadania lub zdarzeniem komunikacyjnym będącym świadectwem pewnych wzorców, praktyk, reguł wytwarzania znaczeń społecznych (Duszak, Fairciough 2008; Kumięga 2013). 
to często ten, który jest albo czarnym charakterem, albo superbohaterem. Wiele negatywnych stereotypów uobecnia się w warstwie fabularnej utworów. Bohater z niepełnosprawnością ukazywany jest z punktu widzenia niezdolności do pełnego uczestnictwa w życiu codziennym i społecznym, a niepełnosprawność staje się głównym komponentem jego charakterystyki (zamiast ukazania napięć między mocnymi i słabymi cechami) (Śmiechowska-Petrovskij 2017).

Prace empiryczne, podejmujące zagadnienie dyskursów niepełnosprawności w literaturze dziecięcej i książkach dla dzieci, nie są liczne. W badaniach zagranicznych problematyka ta była domeną Joan K. Blaska (2003, 2004). W latach 90. Blaska i Lynch przeanalizowali 500 nagrodzonych książek dla dzieci (polecanych dla dzieci w wieku od urodzenia do ósmego roku życia), publikowanych w Stanach Zjednoczonych w latach 1987-1991. Jedynie dwa proc. z tych książek ukazywały bohatera niepełnosprawnego (w przedstawianej historii lub na ilustracjach). Tylko w sześciu książkach taki bohater był integralną częścią fabuły (Blaska 2004).

Badaniom poddawano również wiedzę rodziców i nauczycieli na temat tekstów kultury mówiących o niepełnosprawnym bohaterze (Blaska 2003). Dorośli nie znali publikacji podejmujących temat niepełnosprawności i nie wiedzieli również, w jaki sposób właściwie $\mathrm{z}$ takich tekstów korzystać. W innym badaniu analizie poddano środowisko przedszkolne pod kątem obecności w nim publikacji podejmującej problematykę niepełnosprawności. Spośród 1677 książek udostępnianych dzieciom do samodzielnego zapoznawania się, tylko 1,4 proc. tekstów zawierało tematykę niepełnosprawności. Podczas gdy w 73 proc. placówek dzieci miały dostęp do 1-10 książek związanych ze zróżnicowaniem kulturowym, w 57 proc. klas nie było ani jednej książki podejmującej problematykę niepełnosprawności i choroby. W 42 proc. klas znajdowały się jedna lub dwie takie pozycje (Blaska 2004).

W Polsce brak znaczących badań podejmujących wzmiankowaną problematykę. Analizie najczęściej poddawane są podręczniki szkolne i programy nauczania pod kątem obrazowania niepełnosprawności, wybory nauczycieli na rzecz dzieci w odniesieniu do tekstów podejmujących zagadnienie niepełnosprawności oraz stereotypy dotyczące niepełnosprawności, utrwalane w tekstach kultury (por. Sadowska 2005; Nowicka 2004²; Czerwińska 2014, Śmiechowska-Petrovskij 2014a). Stwierdza się w nich:

- transmisję uproszczonych schematów pojęciowych dotyczących funkcjonowania osób z niepełnosprawnościami (np. łączenie niepełnosprawności wzrokowej z wybitnymi zdolnościami muzycznymi);

- tendencję do stałego pozycjonowania ról społecznych w warstwie fabularnej (pełnosprawny rówieśnik prezentuje postawę pomocową, a osoba z niepełnosprawnością jest jej wdzięcznym odbiorcą);

2 Wyniki badań S. Sadowskiej i M. Nowickiej analizowałam w publikacji pt. Aspekty stygmatyzacji i stereotypizacji osób niewidomych oraz tendencje przeciwstawne. Od stereotypu do wykluczenia (2014). Fidelus A. (red.). Warszawa: Wydawnictwo UKSW. 
- koncentrację na różnicach pomiędzy pełnosprawnymi i niepełnosprawnymi postaciami;

- ukazywanie osób z niepełnosprawnościami w klimacie nostalgii, smutku, melancholii, samotności, pragnienia kontaktu z rówieśnikami;

- niepodejmowanie przez nauczycieli aktywności zmierzających do przepracowania $\mathrm{w}$ interakcjach $\mathrm{z}$ uczniami tych tekstów literackich, które utrwalają stereotypy lub błędne przekonania na temat jednostek z niepełnosprawnościami;

- uznanie przez pedagogów wartości utworów literackich podejmujących problematykę niepełnosprawności, zarówno w odniesieniu do pracy z dziećmi pełnosprawnymi, jak i z uczniami z dysfunkcjami, głównie ze względu na jej prointegracyjny charakter.

W tych analizach uwidacznia się również swoistość relacji nadawczo-odbiorczej w komunikacji literackiej, uwzględniającej temat niepełnosprawności: podmiotem zainteresowań są dorośli pośrednicy (nauczyciele, wychowawcy, rodzice) lub dzieci pełnosprawne (uczniowie) - jako odbiorcy, zaś książka pełni funkcję impresywną, służebną wobec zadań dydaktyczno-wychowawczych i społecznych (integracyjnych). Dziecko z niepełnosprawnością jako odbiorca literatury znajduje się poza obszarem zainteresowań badawczych.

\section{Kryteria wyboru literatury dziecięcej i książek dla dzieci podejmujących temat niepełnosprawności}

W literaturze przedmiotu nieco więcej miejsca poświęca się kryteriom wyboru tekstów literackich podejmujących problematykę niepełnosprawności (Blaska 2004; Blanda, Gannb, Śmiechowska-Petrovskij 2014b). Interesującym narzędziem, niepopularyzowanym dotąd w Polsce, które może okazać się wsparciem dla dorosłych pośredników w procesie wyboru literatury dziecięcej i książek dla dzieci, jest kwestionariusz The Images \& Encounters Profile (Blaska 2004). Zaproponowano w nim dziesięć kryteriów dotyczących publikacji uwzględniającej tematykę niepełnosprawności:

1. Promowanie empatii, nie litości;

2. Obrazowanie akceptacji, nie ośmieszania, szyderstwa;

3. Podkreślanie sukcesów, nie porażek;

4. Budowanie pozytywnego wizerunku osoby z niepełnosprawnością lub chorobą;

5. Towarzyszenie dzieciom w osiąganiu właściwego zrozumienia niepełnosprawności lub choroby;

6. Ukazywanie szacunku dla osób z niepełnosprawnością lub chorobą;

7. Promowanie stosunku do osób $\mathrm{z}$ niepełnosprawnością $\mathrm{w}$ ujęciu ,jeden z nas", zamiast ,jeden z nich"; 
8. Używanie języka ukazującego na pierwszej pozycji osobę, a później jej dysfunkcję („Ania, która jest niewidoma” versus „niewidoma Ania”);

9. Opisywanie osób z niepełnosprawnością jako realnych jednostek (nie jako podludzi lub nadludzi).

10. Przedstawianie bohaterów w sposób realistyczny.

Rekomendowanymi pozycjami będą te, $\mathrm{w}$ których ocenach dominantę stanowią konstatacje twierdzące. W sytuacji dylematu poleca się ponadto odpowiedź na pytanie, czy dana książka zawstydzi lub upokorzy dziecko z niepełnosprawnością, czy też nie?

Powyższe kryteria z pedagogicznego punktu widzenia mają ogromne znaczenie. Są efektem krytycznej analizy zjawisk związanych dyskursami niepełnosprawności w literaturze i książkach dziecięcych (konstatują negatywne fakty społeczne związane z literaturą dziecięcą uwzględniającą zagadnienia niepełnosprawności), a jednocześnie są konkretnym „programem pozytywnym” - narzędziem wspierającym refleksyjne podejście do wyborów książkowych na rzecz dzieci. Szczególnie wartościowy w tej perspektywie jest fakt, iż głównym podmiotem zainteresowania staje się tu odbiorca $\mathrm{z}$ niepełnosprawnością.

Warto jednak dokonać pewnego zastrzeżenia. Pedagogicznym kryteriom wobec sztuki, w tym literaturze i książkom dziecięcym, można postawić zarzut redukcyjności. Gdy spojrzymy na dzieło sztuki jako na współistnienie wymiaru etycznego i estetycznego, okaże się, że kryteria pedagogiczne eksponują jedynie pierwszy wymiar - etyczny. Interesujące wydaje się wyzyskanie obu tych wymiarów w recepcji literatury przez młodych odbiorców, również w odniesieniu do problematyki niepełnosprawności. Uwzględniając ten postulat, zaprezentowano poniżej trzy książki dla dzieci, w których problematyka niepełnosprawności podjęta została w alternatywny sposób.

\section{Kwestie etyczne i estetyczne a literatura dziecięca i książki dla dzieci o niepełnosprawności}

Pierwszą z książek poświęconych tematyce niepełnosprawności jest powieść Andreasa Steinhöfela, niemieckiego pisarza i tłumacza, pt. Rico, Oskar i głębocienie (2011). Książka opowiada o perypetiach Rico, niepełnosprawnego intelektualnie chłopca i jego przyjaźni z Oskarem, chłopcem odmiennym somatycznie, choć nadzwyczaj inteligentnym. Ich wspólna przygoda zakończona zostaje rozwikłaniem tajemniczej zagadki kryminalnej (porywacza dzieci), ale przede wszystkim zbudowaniem głębokiej relacji osobowej. Książka utrzymana jest w konwencji powieści detektywistycznej. Narracja ma charakter pierwszoosobowy - opowieść jest relacją pamiętnikową Rico. Co typowe dla literatury dziecięcej, w powieści ukazana jest galeria postaci ludzkich, zamieszkujących berlińską kamienicę, w której żyje główny bohater. Jak jednak zauważa Joanna Olech (2011), nie przypominają oni 
stereotypowych dorosłych z wypisów szkolnych. Niezwykle barwne osobowości i sytuacje $z$ ich udziałem są bazą do budowy wątków humorystycznych w powieści.

Konstrukcja głównych bohaterów literackich opiera się na ich skontrastowaniu, które dotyczy zarówno aspektów fizycznych (wygląd postaci: Rico - wysoki i masywny, Oskar - niskiego wzrostu, nosi kask i ma wystające zęby), jak i intelektualnych (niepełnosprawność intelektualna - ponadprzeciętna inteligencja), a także nastawienia do życia (Rico - postawa pozytywna, optymizm, Oskar - postawa lękowa, negatywizm, nieufność). Skontrastowanie bohaterów wpisuje się w model wyraźnej polaryzacji cech i postaw postaci, ułatwiający ich percepcję przez młodszego odbiorcę. Celem skontrastowania bohaterów nie jest jednak ukazanie wyłącznie różnic, „amplitudy” psychospołecznego i fizycznego funkcjonowania, ale raczej komplementarności przymiotów i ról (duży odważny, ale mało inteligentny versus mały pełen lęków, wybitnie inteligentny), wzmacniającej więzy międzyosobowe. Taka prezentacja bohaterów pozwala także na zweryfikowanie idealizującego przekonania o życiu osób, które nie doświadczają podobnych deficytów.. Brak niepełnosprawności nie determinuje jednak szczęśliwego i bezproblemowego funkcjonowania, każdy bowiem mierzy się ze swoimi słabościami.

Nagle zauważyłem, co nas różni: ja zwykle mam dobry humor, ale nie wiem zbyt dużo. Oskar natomiast wie bardzo dużo zadziwiających rzeczy, za to często jest niezadowolony. Chyba dlatego, że gdy jest się mądrym, to człowiekowi do głowy przychodzą nie tylko same piękne myśli, ale też kilka strasznych (Steinhöfel 2011, s. 65).

Niepełnosprawność intelektualna zaprezentowana jest w powieści jako problem Rico z liczeniem, określaniem kierunków i stron świata oraz z zapamiętywaniem. Wyzyskiwanym sposobem obrazowania jest ruch kul bingo w głowie bohatera, ukazujący jego intelektualne zmagania. Rico określa siebie jako chłopca „głęboko utalentowanego" (dzięki przekazowi mamy). Ta peryfraza dla „głęboko upośledzonego" nie niweluje jednak treści kryjącej się pod tym klasyfikującym określeniem. Bohater jest świadomy swoich ograniczeń i negatywnych nastawień społecznych względem niego. Choć prezentuje dystans wobec siebie, wrażliwie reaguje także na przejawy pejoratywnych reakcji otoczenia. Jego zdolność do introspekcji i mentalizacji znajduje swój wyraz we fragmentach utworu bezpośrednio odnoszących się do niepełnosprawności, jak np. w poniżej cytowanym fragmencie

- Ty naprawdę jesteś głupi, no nie? Bo przecież, jeśli się coś widzi i trzeba iść do tego prosto, to trudno się wtedy zgubić.

No przynajmniej zgadzała się prawa strona. Mimo to się wkurzyłem. - Czyżby? A ja potrafię się zgubić. Gdybyś rzeczywiście był taki mądry, jak mówisz, to byś wiedział, że są ludzie, którzy potrafią się zgubić. $-\mathrm{Ja} .$. 
- I jeszcze coś ci powiem. To wcale nie było śmieszne! - Wszystkie kule bingo zrobiły się czerwone i zaczęły się obijać o siebie. - Wcale nie chcę, żeby mi ciągle coś uciekało z głowy! Nie jestem głupi z wyboru ani dlatego, że się czegoś nie nauczyłem! (Steinhöfel 2011, s. 34-35).

Zmiana perspektywy oglądu niepełnosprawności intelektualnej poprzez relację pierwszoosobową bohatera jest przekonywująca, również dzięki racjonalności wykładni Rico. Pomaga ona zrelatywizować tradycyjne myślenie o różnicy:

- Czy mógłby pan za mnie sprawdzić drogę? Nie umiem sobie z tym poradzić - przyznałem się niechętnie.

- Z powodu twojego upośledzenia, prawda?

Jak beztrosko to powiedział i znów się uśmiechnął! Musiałem zacisnąć zęby, żeby zachować spokój [...] To naprawdę irytujące, kiedy ludzie uważają kogoś za kompletnego idiotę, tylko dlatego, że robi coś wolniej niż oni. To jakby mój mózg próbował kierować samochodem bez kierownicy. W końcu ja się nie skarżę, że inni myślą zbyt szybko, albo że ktoś sobie wymyślił cztery kierunki świata oraz lewą i prawą stronę, albo piekarnik z dwudziestoma siedmioma różnymi funkcjami tylko po to, żeby w nim odświeżyć głupią bułkę.

- Nie jestem głęboko utalentowany przez zachciankę, a poza tym tylko trochę - odpowiedziałem ze skwaszoną miną i wskazałem plan miasta. - Po prostu czasem nie wiem, gdzie jest przód, a gdzie tył, i takie rzeczy (Steinhöfel 2011, s. 136).

Osią dyskursu o niepełnosprawności w powieści Rico, Oskar i głębocienie jest interakcyjność i relacyjność jednostek pełnosprawnych i nieposiadających dysfunkcji. Oprócz przyjaźni pomiędzy Rico i Oskarem, Steinhöfel ukazuje także przyjaźń niesłyszącego Svena i Feliksa.

Szczeciniasty u jego boku dalej nie odezwał się ani słowem. Musiał robić dwa razy tyle kroków, co Feliks, ale dzielnie za nim dreptał, jakby był przywiązany niewidzialną smyczą.

- Zawsze mu opowiadam o nowych pomysłach - powiedział Feliks. - A jeśli mu się spodoba jakaś historia, to ją spisuję. Wcześniej nie.

Pewnie mu przeszkodziłem w opowiadaniu Svenowi o nowej historii. Uniosłem rękę i pomachałem do Svena.

- Witaj, Sven.

Żadnej odpowiedzi. Sven nawet na mnie nie spojrzał.

- On Cię nie słyszy - powiedział Feliks. - Nie może też mówić. Jest głuchoniemy.

- Nie mówi się głuchoniemy, tylko niesłyszący - wiedziałem o tym ze szkoły specjalnej. 
- Wszystko jedno jak się mówi. - Feliks szedł coraz szybciej, patrząc przed siebie. - Najważniejsze, że ktoś mnie w ogóle słucha. [...] Spoglądałem chwile za nimi. Jak bardzo trzeba być szalonym, żeby niesłyszącemu opowiadać historie? I jak szalonym trzeba być, żeby wysłuchiwać kogoś, nie słysząc? Ale ani Feliks, ani Sven nie wstydzili się tego. Ich niezwykła przyjaźń nie wprawiała ich w zakłopotanie. Wprost przeciwnie. Dla nich była najoczywistszą sprawą na świecie. I to sprawiło, że natychmiast poczułem się lepiej (Steinhöfel 2011, s. 143-144).

Wyeksponowanie przyjaźni i symetrii w relacji zbudowanej na subiektywnie postrzeganej wymianie dóbr, niezdeterminowanej znaczniejszą sprawnością psychofizyczną jednej ze stron, jest istotną zmianą w stosunku do jednokierunkowych relacji pomocowych, jakie istnieją pomiędzy pełnosprawnymi i niepełnosprawnymi bohaterami, co jest zresztą najczęściej ukazywanym motywem w literaturze dziecięcej. Zamiast relacji zawiązywanych ze względu na czynnik niepełnosprawności i konieczność udzielenia wsparcia, pomocy, pojawiają się też relacje zawiązywane między jednostkami mimo faktu niepełnosprawności.

W powieści nie idealizuje się jednak interakcji społecznych z udziałem osób z niepełnosprawnościami. Rico i Oskar doświadczają szykan i innych negatywnych reakcji ze względu na swoją inność.

Znieruchomiały Oskar nawet nie mrugnął powieką, kiedy porywacz zbliżył swoją prostokątną twarz do jego twarzy.

- Jesteś najokropniejszym dzieckiem, jakie kiedykolwiek spotkałem! ofuknął go Marrak. - Wiesz, za kogo by cię uważano w średniowieczu? Za odmieńca, potwora! Karę boską! Jeszcze czterysta lat temu takie bachory publicznie palono na stosie! (Steinhöfel 2011, s. 196).

Ale także za pozytywnymi z pozoru reakcjami kryją się ambiwalentne afektywne motywacje:

Nagle zrozumiałem coś okropnego, że ludzie tylko dlatego odnoszą się do mnie w miarę przyjaźnie, bo uważają mnie za niepełnosprawnego. A tak naprawdę strasznie ich denerwuję (Steinhöfel 2011, s. 164).

Przedstawienie tych problemów w optyce głównego bohatera powoduje, że znika z powieści dydaktyczny ton rekapitulujący utwór w warstwie ideowej, o co łatwo, gdy mowa o tematach ważnych, ale trudnych społecznie, jak stosunek do osób $\mathrm{z}$ niepełnosprawnością. Drugim elementem, jaki niweluje ryzyko sentymentalizmu lub patosu w ukazywaniu niepełnosprawności, jest humor i komizm językowy, którymi przesycona jest powieść. 
To, co jednak najistotniejsze w odniesieniu do dyskursu niepełnosprawności w powieści Andreasa Steinhöfela, to fakt, iż głównymi tematami utworu są zagadka kryminalna, przygoda i przyjaźń. Elementy wyeksponowane w powyższych rozważaniach, odnoszące się do problematyki niepełnosprawności, subtelnie przeplatają się z głównymi wątkami, z barwnymi postaciami, z innymi elementami ciągu zdarzeń. Problematyka niepełnosprawności, choć wyraźnie zarysowana, nie ma charakteru autotelicznego w powieści.

Kolejną interesującą pozycją literacką jest książka obrazkowa Dźwięki kolorów, autorstwa Jimmiego Liao (2012). Książkę zadedykowano poetom. Jej mottem są słowa Wisławy Szymborskiej: „Wielkie to szczęście nie wiedzieć dokładnie, na jakim świecie się żyje”, posłowiem - wiersz Rainera Marii Rilkego Ślepa. Ta rama wyznacza zarówno formę, jak i treść utworu. Książka w warstwie literackiej jest poetyckim, pierwszoosobowym monologiem. Częściowo przedstawia zdarzenia wędrowanie ociemniałej, niewidzącej dziewczynki tunelami metra, schodami ruchomymi, pociągami, a częściowo metaforycznym wyznaniem dotyczącym przeżyć, marzeń, potrzeb, wyobrażeń oraz życiowym credo. Ilustracje towarzyszące tekstowi wzbogacają sens całego komunikatu artystycznego. Są źródłem dodatkowych odniesień literacko-kulturowych. Można znaleźć na nich postacie literackie, motywy z malarstwa. Współbrzmienie obrazów i słów prezentowanych symultanicznie poszerza zakres znaczeniowy tekstu o dodatkowe konteksty interpretacyjne, choć sama warstwa werbalna dzieła jest nośnikiem najważniejszych znaczeń utworu.

Mimo że utwór rozpoczyna się jak opowieść o jednostkowym, osobowym doświadczeniu:

Tamtego roku, kiedy anioł przy wejściu do metra pożegnał się ze mną, traciłam wzrok, stopniowo, powoli.

W jesienny poranek mych piętnastych urodzin, gdy za oknem siąpiła mżawka, nakarmiłam kota i o szóstej pięć weszłam do metra.

Ostrożnie, bez końca, schodziłam w podziemne tunele [...].

Poprzez konwersje czasowe (czasu przeszłego na teraźniejszy i odwrotnie), zmiany form orzekających na pytające oraz wprowadzanie zwrotów w drugiej osobie, następuje pęknięcie kanwy fabularnej. Umożliwia ono formułowanie zdań wieloznacznych, niedosłownych. Naddatki znaczeniowe pobudzają do refleksji osobistej, egzystencjalnej. Nie zawsze czytelnik ma świadomość, że część tych fraz ma charakter deskryptywny w odniesieniu do specyfiki funkcjonowania osób $\mathrm{z}$ niepełnosprawnością wzrokową:

Jeśli wszystkie linie świata łączą się ze sobą, czy mogą mnie zawieźć wszędzie, gdzie zamarzę?

W zatłoczonym wagonie zgubiłam poczucie kierunku. 
Wyobrażenia i fantazje odnoszą się do realności:

Wyobraziłam sobie cyrkowe słonie, jeden za drugim drepczące powoli w szeregu - ich ciężkie kroki uspokoiły mnie trochę.

Słowom tym towarzyszy ilustracja obrazująca schody prowadzące z peronu metra w górę, kilka słoni w kolorowych kubraczkach i niewidomą dziewczynkę idącą za nimi z białą laską. Siła wyobraźni przekształca wrażenia słuchowe (jednostajny rytm kroków dużej liczby osób) w przesyconą elementami fantastycznymi scenę.

Czasem mam wrażenie, że świat nie ma granic. [...] Czasem mam wrażenie, że świat to labirynt pozbawiony wyjścia. [...]

Po licznych upadkach dopiero pojęłam,

że wielu rzeczy za mocno nie należy pragnąć.

Te uwagi o naturze ogólnej, które w formie metaforycznej mógłby wyrazić każdy, zyskują nowy wymiar, gdy przyjmie się perspektywę osoby nieposługującej się wzrokiem. Konieczność korzystania z dotykowych i słuchowych wskazówek płynących z otoczenia podczas poruszania się i brak kontroli wzrokowej mogą powodować wrażenie braku wskaźników położenia w przypadku niewystarczającej liczby informacji lub w przypadku dużej liczby bodźców trudnych do interpretacji wrażenie złożoności otoczenia fizycznego utrudniającego orientację w przestrzeni.

Czy wczorajsza stacja różni się czymkolwiek od dzisiejszej?

To pytanie nie dotyczy tylko sytuacji odwiedzania różnych stacji. Może dotyczyć różnicy w postrzeganiu słuchowo-dotykowo-kinestetycznym tej samej przestrzeni $\mathrm{w}$ innych okolicznościach, jak również różnic w postrzeganiu, wynikających z odmiennych emocji czy doświadczeń danej osoby - niezwiązanych z możliwościami sensorycznymi.

Waga niepełnosprawności wyrażona jest pytaniem:

W mieście nieustanne gubię drogę.

bez przerwy źle wsiadam

i błędnie wysiadam.

Często nie wiem gdzie jestem, ani dokąd zmierzam.

Zamyślona często zbaczam na zamglone bagna,

skąa $z$ trudem się wydostaję.

Na szczęście, mój anioł wciąż czuwa nade mną.

Pytasz mnie o drogę do domu i wpadam w panikę.

Różnię się od innych, czy tego nie widzisz? 
...oraz wyznaniem ze skargą, która jednak zostaje przepracowana:

Świat nagle zgasł! Kto tak żarty stroi?

Szukam po omacku, ale źródła światła odnaleźć nie mogę.

Za rogiem ktoś śpiewa - cicho, z melancholią.

Czy śpiewająca tak jak ja się smuci?

Całą swoją mocą, wciąż szukam nadziei,

boję się okropnie, że przegapię szczęście

stojące tuż przy moim boku.

$[\ldots]$

Zanim się poznamy, już się rozchodzimy,

raz za razem w metrze rozłączamy dłonie.

$[\ldots]$

Przy wyjściu z metra wybucham szlochem,

czy tylko dlatego, że w metrze został mój parasol?

$[\ldots]$

Wczorajsze smutki poszły w niepamięć.

Udało się zapomnieć? To znaczy - było nieważne.

Dyskurs niepełnosprawności oparty jest na wyrażanych trudnościach i lękach związanych z zaspokojeniem potrzeb - ogólnoludzkich, uniwersalnych (bliskich relacji, szczęścia, spełnienia). Dyskurs ten prowadzony jest symultanicznie z dyskursem egzystencjalnym. Gdy bohaterka stwierdza: „Często nie wiem, gdzie jestem, ani dokąd zmierzam", a ilustracja przedstawią ją w drewnianych wagonikach kolejki zamalowanych motywami z obrazów Paula Gauguina (nawiązanie do Skąd przyszliśmy? Kim jesteśmy? Dokad idziemy?), to staje się jasne, że tym, co konstruuje utwór i jego sposób odczytania, jest multiplikacja perspektyw: to, co pisane „uniwersalnie”, dzięki wiedzy o funkcjonowaniu osób niewidzących, staje się formą deskrypcji ich doświadczeń, a to, co posiada znaczniki personalizacji (niewidzenia), może być znaczące w ogóle - dla różnych odbiorców.

Ostatnią z przywoływanych pozycji jest Czarna książka kolorów (M. Cottin, R. Fara 2013).

Jest to książka konceptualna - składa się z czarnych stron, białego druku oraz zapisów brajlowskich (czarne wypukłe punkty na czarnych stronach). Zawiera także ilustracje wypukłe (czarne wypukłe elementy na czarnym tle). W warstwie treściowej zaś ta opowieść paradoksalnie dotyczy kolorów; tego, jak Tomkowi jawią się barwy. Jest przeznaczona dla dzieci młodszych (cała treść ujęta jest w dziesięciu zdaniach).

„Dla Tomka kolor żółty ma smak musztardy, ale jest mięciutki jak piórka kurczątek" - tymi słowami rozpoczyna się utwór. Kolejno pojawiają się omówienia koloru czerwonego, brązowego, niebieskiego, białego, zielonego i czarnego. Pojawia się również odniesienie do tęczy i do obiektów bezbarwnych. 
W narracji, dotyczącej percepcji barw przez chłopca, wykorzystano zjawisko kompensacji słuchowo-dotykowo-kinestetyczno-węchowo-smakowej w budowaniu wyobrażeń surogatowych - wyobrażeń tych treści, które są niedostępne bezpośrednio poznaniu zmysłowemu, jak w przypadku barw - wzrokowemu. Na bazie więc pozawzrokowych, lecz polisensorycznych doznań oraz wysoce subiektywnych doświadczeń emocjonalnych powstają umysłowe reprezentacje kolorów. W ich tworzeniu ważne miejsce zajmuje mechanizm analogii - zestawiania elementów na bazie podobieństwa, często bardzo subiektywnego.

Czerwony jest kwaśny jak truskawka i słodki jak arbuz. Kolor czerwony boli, kiedy wygląda spod zadrapanej skóry na jego kolanie.

Kolor brązowy szeleści mu pod stopami, kiedy liście są suche. Czasami pachnie czekoladą, a kiedy indziej bardzo brzydko.

Występująca we frazach synestezja odgrywa podwójną rolę. Z jednej strony jest tropem stylistycznym, dzięki któremu transponowane jest doświadczenie charakterystyczne dla danego kanału poznawczego na wrażenia innego typu, a jego użycie może być tłumaczone względami artystycznymi. $Z$ drugiej strony staje się formą deskrypcji sposobu poznawania świata przez osoby niewidzące - jej wykorzystanie sygnalizuje właściwości psychologiczne jednostek niewidomych.

A królem kolorów jest czarny. Jest delikatny jak jedwab - tak jak wtedy, kiedy mama przytula Tomka i okrywa go swoimi długimi włosami. Tomek lubi wszystkie kolory, bo je słyszy, czuje ich zapach, dotyk i smak.

Zestawienie jednolitych czarnych stron, zawierających jedynie białe litery, z treścią dotyczącą kolorów jest rodzajem relacji nadawczo-odbiorczej stawiającej przed adresatem widzącym zadanie odwołania się do doświadczeń i wyobraźni, ażeby pogłębić swoją percepcję barw. Ponadto bez dodatkowych słów wprowadzenia i objaśnienia odbiorca buduje obraz niewidomego bohatera (to obecność liter brajlowskich i grafiki wypukłej odnosi do niewidzenia chłopca), poznając jego sposób odbierania elementów rzeczywistości typowo wzrokowych. Swoistą lekcją o niepełnosprawności jest takie zaprojektowanie książki, aby mogli ją czytać zarówno widzący, jak i niewidomi. Dodatkowo, dzięki umieszczeniu na ostatniej stronie alfabetu brajlowskiego, widzący mogą nauczyć się systemu Braille’a i odczytywać zamieszczone fragmenty w alternatywny sposób.

\section{Pedagogiczne zastrzeżenia}

Oczywiście w analizie pozycji książkowych skierowanych dla dzieci, zwłaszcza uwzględniających problematykę niepełnosprawności, z perspektywy pedagogicznej szczególnym polem odniesień jest kwestia utrwalania stereotypów lub 
przekazywania nierzetelnych informacji o jednostkach doświadczających dysfunkcji. Również w przypadku analizowanych pozycji pojawia się kilka kwestii wymagających krytycznej refleksji:

- Czy zdolność do mentalizacji, autorefleksji i głębokiej introspekcji jest reprezentowana przez osoby z niepełnosprawnością intelektualną na takim poziomie, jak ukazano to w książce Rico, Oskar i głębocienie?

- Obrazowanie graficzne dziewczynki z białą laską w Dźwiękach kolorów nie zawsze jest zgodne z zasadami orientacji przestrzennej i samodzielnego bezpiecznego poruszania się (np. dziewczynka jadąca w górę schodami ruchomymi trzyma laskę wyciągniętą do góry, jakby nią na coś wskazywała). Czy względy artystyczne wystarczająco uzasadniają tę rozbieżność?

- Czarna ksiażka kolorów pośrednio sugeruje, że „ślepota jest czarna”, co nie jest zgodne z wiedzą medyczną.

- Grafika dotykowa, znajdująca się w Czarnej książce kolorów, nie jest zredagowana według zasad opracowywania tyflografik i nie jest czytelna, dostępna dla odbiorców niewidomych, mimo założeń twórców.

Powyższe punkty nie umniejszają walorów omawianych publikacji, prowokują jednak do ich przepracowania w procesie komunikacji czytelniczej dzieci.

\section{Podsumowanie}

Omówione trzy pozycje książkowe reprezentują alternatywny sposób ujmowania problematyki niepełnosprawności w literaturze dziecięcej i książkach dla dzieci. Choć dyskurs niepełnosprawności jest wyraźny do wyodrębnienia, sama problematyka nie stanowi semantycznej dominanty. $\mathrm{W}$ warstwie treściowej najwięcej deskrypcji związanych $\mathrm{z}$ funkcjonowaniem osób z niepełnosprawnością oraz sądów dotyczących zjawiska niepełnosprawności, różnicy, inności zawartych jest w książce Andreasa Steinhöfela. Wynika to m.in. z możliwości gatunkowych powieści. W Dźwiękach kolorów z kolei zwielokrotnienie możliwości odczytania sensu utworu (na poziomie ogólnym - przez każdego odbiorcę, na poziomie specyficznym - przez odbiorcę z dysfunkcją wzroku) czyni z tej książki obrazkowej przestrzeń dywersyfikującą i zarazem integrującą. Czytelnik niewidomy może odnaleźć w słowach wyznania lirycznego swoje doświadczenia, te fizyczne i emocjonalne, ale dzięki metaforyczności tekstu także odbiorca bez dysfunkcji ma sposobność utożsamienia się z treściami monologu wewnętrznego. Czyni to lekturę jednocześnie możliwą do wspólnych odczytań, jak i jednostkową. W Czarnej książce kolorów wspólnotę czytelniczą zaakcentowano poprzez włączenie druku wypukłego (brajlowskiego) w obręb publikacji, tworząc książkę brajlowsko-czarnodrukową. Przez tematykę utworu - problematyką percepcji barw przez osoby niewidzące, a także warstwą graficzną (czarne strony, biały tekst) oraz edycyjną (tekst płaski, tekst wypukły) wprowadzono czytelnika widzącego w świat osób niewidomych, a niewidomym zapewniono dostęp do tej samej pod względem materiałowym 
publikacji. Nie były zatem niezbędne dydaktyzujące opisy i wyjaśnienia. Stworzono tym samym płaszczyznę do samodzielnej rekonstrukcji sensów przez młodego adresata, zapobiegając transmisyjno-adaptacyjnym procesom związanym z przekazem przekonań i wartości uznanych za społecznie pożądane do przekazania.

Literalnie utwory te nie proponują wykładni podejścia do zjawiska niepełnosprawności. Tym samym nie redukuje się tu literatury i książki dziecięcej do pełnienia wyłącznie społecznej misji w edukowaniu o niepełnosprawności - nie czyni się z treści książek środka dydaktycznego, wspierającego właściwy przekaz o osobach niepełnosprawnych. Ten przekaz oczywiście następuje, ale proporcja warstwy etycznej i estetycznej utworów jest wyrównana. Jak pisze Susan Sontag:

„Dzieło sztuki odbierane jako dzieło sztuki jest doświadczeniem, nie przesłaniem ani odpowiedzią na pytanie. Sztuka jest nie tylko o czymś, sama w sobie jest czymś. Dzieło sztuki to obiekt w świecie, a nie komentarz lub tekst na temat świata" (Sontag 2012, s. 35).

Tym samym edukowanie przez sztukę, celem uczestnictwa w świecie rzeczywistym, może odbywać się równolegle z edukowaniem do sztuki. Kontynuując myśl Sontag trzeba stwierdzić, że:

„Oczywiście sztuka [...] odnosi się do świata rzeczywistego - do naszej wiedzy, doświadczenia, wartości. Przedstawia informacje i oceny. Charakterystyczną cechą dzieł sztuki jest jednak to, że prowadzą nie do wiedzy pojęciowej [...] lecz do swoistej ekscytacji, zaangażowania [...]. Wiedza zdobyta dzięki sztuce jest więc doświadczeniem formy lub stylu, w jakich coś wiemy, a nie wiedzą o czymś (jak znajomość faktów lub osąd moralny) samą w sobie" (Sontag 2012, s. 36).

Wartościowe wydaje się zachęcanie dorosłych pośredników, wybierających pozycje lekturowe o niepełnosprawności - zarówno dedykowane dzieciom bez utrudnień w funkcjonowaniu psychofizycznym, jak i z dysfunkcjami, do uwzględnienia powyżej zarysowanej perspektywy w procesie wychowania.

\section{Bibliografia}

Blaska J.K. (2003). Using children's literature to learn about disabilities and illness. New York: Educator's International Press.

Blaska J.K. (2004). Children's literature that includes characters with disabilities or illnesses. „Disability Studies”, 1/2004.

Connor D.J., Gabel S.L. (2009). Welcoming the Unwelcome: Disability As Diversity. W: Social justice in pedagogy in the United States: The practice of freedom. Hobbel N., Chapman T. New York, London: Routledge.

Cottin M., Fara R. (2013). Czarna książka kolorów. Piaseczno: Widnokrąg.

Czerwińska K. (2014). Wizerunek osób niewidomych w literaturze dziecięcej-przełamywanie czy kształtowanie stereotypów? „Wychowanie na co dzień”, 1.

Kaney P. (2013). Representations of Disability in Youth Literature: A Discourse Analysis of Award Winning Books. USA: Emporia State University. 
Krytyczna analiza dyskursu. Interdyscyplinarne podejście do komunikacji społecznej. (2008). Duszak A., Fairciough N. (red.). Kraków: Universitas.

Liao J. (2012). Dźwięki kolorów. Łódź: Officyna.

Nowicka M. (2004). Praca z tekstem literackim dla dzieci - szansa czy przeszkoda w edukacji do innego. W: Światy dziecięcych znaczeń. Klus-Stańska D. (red.). Warszawa: „Żak”.

Olech J. (2011). Rico, Oskar i głębocienie. Recenzja. „Magazyn Literacki”, nr 10-11. Oświata i wychowanie w roku szkolnym 2018/2019. Warszawa: GUS.

Rudman M.K. (1995). Children's Literature: An Issues Approach. New York: Longman.

Rudman M.K., Pearce A.M. (1988). For the love of reading: A parent's guide to encouraging young readers from infancy through age 5 . New York: Consumers Report.

Sadowska S. (2005). Ku edukacji zorientowanej na zmianę społecznego obrazu osób niepetnosprawnych. Toruń: Akapit.

Sontag S. (2012). Przeciw interpretacji i inne eseje. Kraków: Karakter.

Steinhöfel A. (2011). Rico, Oskar i głębocienie. Kraków: WAM.

Śmiechowska-Petrovskij E (2014a). Aspekty stygmatyzacji i stereotypizacji osób niewidomych oraz tendencje przeciwstawne. W: Od stereotypu do wykluczenia. Fidelus A. (red.). Warszawa: Wyd. UKSW.

Śmiechowska-Petrovskij E. (2014b). Inny czytelnik-taka sama literatura? Wartościowanie książek literackich dla niewidomych dzieci w młodszym wieku szkolnym przez nauczycieli, wychowawców i bibliotekarzy. W: Miejsce Innego we współczesnych naukach o wychowaniu. Inny w przestrzeni społecznej. Jachimczak B., Pawelczak K., Wojciechowska A. (red.). Poznań: Wydawnictwo Uniwersytetu Adama Mickiewicza.

Śmiechowska-Petrovskij E. (2017). The stigmatizing and stereotyping people with blindness. The opposite tendencies. „Forum Pedagogiczne”, nr 2.

\title{
DISCOURSES OF DISABILITY IN CHILDREN'S LITERATURE
}

\begin{abstract}
Disability and children with disabilities are rarely included in children's literature. Depicting characters with special needs is important because of the process of social inclusion - for children without dysfunctions and for those with some problems in psychophysical functioning. But there are often a lot of stereotypes in literary texts. The aim of this paper is to show cultural textswhich present disability and join ethical and aesthetical values at the same playing field.
\end{abstract}

Keywords: children literature, disability, inclusion, blind people, intellectual disabled, books for children. 